\title{
Sphingosine Kinase 1
}

National Cancer Institute

\section{Source}

National Cancer Institute. Sphingosine Kinase 1. NCI Thesaurus. Code C92513.

Sphing osine kinase 1 (384 aa, $43 \mathrm{kDa}$ ) is encoded by the human SPHK1 gene. This protein plays a role in the phosphorylation of sphing osine. 